\title{
Problemer omkring monopoler og statens rolle*
}

\section{Elmar Altvater}

I diskussionen af den politiske taktik ved opbygningen af en antikapitalistisk, socialistisk bevægelse tager Altvater udgangspunkt i forbindelsen mellem den teoretiske ramme og den politiske taktik.

Han påviser, at revisionismens skarpe skel mellem $\varnothing$ konomi og politik, mellem lønkamp og politisk kamp fører til en amputering af det revolutionære indhold i analysen af kapitalismen.

Denne amputerings konsekvenser for den politiske taktik viser sig i opfattelsen af statens rolle. De forskellige socialdemokratiske teoretikere og Stamokap-teoretikerne mener nemlig, at »værdilovens regulerende evne er sat ud af kraft «, og at især staten nu står som produktionens regulator.

Hvis staten ikke opfattes som en del af de kapitalistiske bevægelseslove (og derfor lader sig aflede af disse bevægelseslove), men som en erstatning for disse, så bliver den politiske taktik til et spørgsmål om kampen om statsmagten, mod monopolerne og deres forbindelse til statsmagten.

Monopolbegrebet spiller en afgørende rolle for Stamokapteoretikernes påstand om bevægelseslovenes ophævelse, hvorfor Altvater analyserer monopolbegrebet nærmere i det afsluttende afsnit. 
Analysen af de kapitalistiske produktionsrelationer har politiske implikationer, og omvendt er det meget ofte således, at de politiske mål bestemmer såvel form som resultat af teoretiske overvejelser angående den nuværende kapitalisme. Desuden er arbejderbevægelsens politiske fraktioner og især arbejderpartierne ofte forskellige med hensyn til deres teorier, hvilket resulterer i særlige politiske forestillinger og taktikker. Dette er ret indlysende i diskussionen omkring den sk. STAMOKAP eller statsmonopolkapitalismen. Teorien om statsmonopolkapitalismen er blevet den næsten helt »officielle« teori i de vestlige landes kommunistiske partier og i den socialistiske verden, og en anden opfattelse end de kommunistiske partiers markeres ofte gennem en »anti-teori « om statsmonopolkapitalisme. Eksempelvis er diskussionen i Vesttyskland om STAMOKAP dels en teoretisk diskussion og dels - mere vigtigt - en diskussion mellem det vesttyske kommunistiske parti og venstre-socialister om den politiske taktik ved opbygningen af en antikapitalistisk, socialistisk bevægelse.

Jeg vil gerne vise denne forbindelse mellem teoretisk ramme og politisk taktik ved nogle eksempler.

1. eksempel: I teorierne om statsmonopolkapitalismen læser man almindeligvis, at monopolerne undertrykker og udplyndrer hele samfundet, eller at hele samfundet er underordnet et par monopoler. Det er klart at dette udsagn får konsekvenser for indgåelsen af politiske alliancer. Hvis det er rigtigt, at monopolerne lever af at udplyndre hele samfundet, så må der være en fundamental interessekonflikt mellem monopolkapitalen og dens stat på den ene side og folkets store masse på den anden side. Derfor udvikler STAMOKAP-teorien en politisk kategori om »de antimonopolistiske kræfter « eller bevægelse, som indgår en meget tæt alliance med den revolutionære arbejderbevægelse. Derfor bliver det en meget vigtig opgave for de kommunistiske partier at skabe og styrke brede antimonopolistiske alliancer. Her viser det sig således, at den teoretiske fortolkning af monopolernes profit som tribut eller underkastelse har politiske konsekvenser med hensyn til opbygning af alliancer mellem alle lag og grupper i samfundet med undtagelse af monopolerne og deres stat.

2. eksempel: Ud fra antagelsen om statens relative autonomi som et politisk reguleringsapparat og ud fra antagelsen om denne stats store betydning for monopolernes magt følger, at staten har en dominerende stilling i samfundet, og at staten må erobres af de antimonopolistiske kræfter. Dette er antimonopolistiske kræfters første mål, fordi der er mulighed for at lægge pres på politikken og for at bekæmpe favoriseringen af monopolerne, samt for at gribe ind mod de fjendtlige forholdsregler, som staten gennemfører. Således bliver det et mål for en kommunistisk taktik at gennemtvinge det antimonopolistiske eller fremskredne demokrati for at indføre en anden politik i staten, et andet indhold i politikken, hvor dette nye indhold udledes af de interesser, som hele den antimonopolistiske del af folket har. Også i dette tilfælde har vi således et eksempel på, at en særlig 
teoretisk opfattelse med hensyn til statens autonomi implicerer en særlig politisk opfattelse, nemlig forestillingen om det antimonopolistiske demokrati.

3. eksempel: Lenin og alle de teoretikere, som bygger på hans arbejder, taler om forfaldstendenserne i statsmonopolkapitalismen. Også denne kategori får taktiske konsekvenser. I forhold til kapitalismens forrådnelse, som i dag gennemløber sin »tredje fase af kapitalismens almene krise « bliver socialismen et realt alternativ, som aftegnes i konkurrencen mellem de to systemer i verden. Dette betyder, at de teoretiske udsagn med nødvendighed implicerer politiske udsagn om kapitalismen og socialismen som reale samfundsmæssige systemer. Især i Vesttyskland indebærer denne teoretisk forklarede politiske stilling en accept af Den tyske Demokratiske Republik.

Disse korte eksempler viser, at der er en sammenhæng mellem teoretisk argumentation og formuleringen af politiske doktriner. Derfor er især samfundsvidenskaberne altid politiske i den forstand, at de er i stand til at formulere forklaringer eller udarbejde gode politiske taktikker. Problemet er dog ikke så gensidigt, som det er formuleret her, fordi enhver teori er ikke i stand til at underbygge og bevise en hvilken som helst politisk taktik. Det er omvendt således, at teoriens struktur og politikkens struktur må være kongruente. Dette argument kan belyses ved at diskutere relationen mellem $\varnothing$ konomi og politik i teori og praksis.

\section{II.}

Forholdet mellem $\varnothing$ konomi og politik har mange dimensioner. For det første kan det transformeres til forholdet mellem de økonomiske bevægelseslove for kapitalakkumulationen og den politiske magt, som staten eller de samfundsmæssige magteliter udøver. Det er typisk for den reformistiske teori og praksis at understrege den rolle, som magt og modgående magt spiller ved reguleringen af de samfundsmæssige systemer og for at tvinge disse til at gennemføre sociale reformer, f.eks. lønforbedringer, større social sikkerhed o.s.v. Den reformistiske teori mener, at kun den $\varnothing$ konomiske magt kan overvindes af arbejderpartiets modgående politiske magt. Reformismen glemmer det betydningsfulde forhold i den kapitalistiske udvikling, nemlig at systemets modsigelser ikke kun er modsigelser med hensyn til økonomisk og politisk magt, men netop modsigelser af en mere principiel natur, idet de skabes af den kapitalistiske systems modsisesfulde udviklingsmåde.

For det andet er der dimensionen $\varnothing$ konomisk og politisk kamp. Dette er en adskillesle, som må forståes som et resultat af den form, som det borgerlige samfund udvikler sig i. Konsekvensen af samfundets fordobling i samfund og stat er en fordobling af arbejdernes kamp i en økonomisk og en politisk kamp. Økonomisk kamp sættes ofte lig lønkamp, mens politisk kamp sættes lig kampen mod den kapitalistiske stat. Men denne distinktion er meget problematisk, fordi den overfører politikkens form i det borgerlige samfund til arbejderklassen. En politisk praksis, som bygger på distinktionen mellem økonomisk og politisk kamp, vil nødvendigvis udvikle sig i borgerlige former. Forestillingen om politik bliver vilkårlig, 
både når politik kun opfattes som et vedhæng til kapitalens bevægelse og når teoretikere og politikere mener, at kapitalen og staten manipulerer samfundet, som det proletariske parti så må modarbejde bevidst. Men man må langt snarere gå ud fra et begreb om kapitalens herredømme, som indeholder såvel økonomiske som politiske udtryksformer i det samfundsmæssige liv. Kapitalens herredømme er totalt og totalitært i den forstand, at det påvirker og determinerer hele samfundets struktur, hvorfor det strukturerer den økonomiske kamp som en politisk kamp og den politiske kamp som en $\varnothing$ konomisk. Derfor er det teoretisk og politisk forkert udelukkende at definere en politisk bevægelse som en bevægelse, der kæmper mod den borgerlige stat som den herskende klasses kollektive magt. Det er langt mere interessant at forstå de mange overgange fra økonomisk til politisk kamp og at forstå det politiske indhold i de økonomiske krav og den økonomiske kamp.

For det tredje er der den unge Marx' distinktion mellem menneske og borger eller homme og citoyen. Dette er en kategorial overførelse af samfundets fordobling i samfund og stat til det kapitalistiske individ, som fordobles på samme måde. Som borger agerer det kapitalistiske individ som agent for den kapitalistiske produktions love, men som menneske agerer det som et tilsyneladende frit og lige individ. Som borgere er der forskelle mellem den proletariske arbejder og kapitalisten, da deres $\varnothing$ konomiske funktioner ikke blot er forskellige, men også modsigelsesfulde. Men som mennesker er de alle lige og frie, og alle forskelligheder udviskes. På det $\varnothing$ konomiske plan får kapitalisten profit og arbejderen løn, men som mennesker får de alle en indtægt, som ikke er kvalitativt forskellig, kun kvantitativt. På denne måde opstår alle de illusioner, der er forbundet med det borgerlige samfund og den borgerlige ideologi. Denne er ikke kun en illusion, som er produceret forsætligt af nogle ideologiproducenter, men netop en illusion, som er indbygget i de samfundsmæssige formers struktur, hvori samfundet reproducerer sig selv. Samfundets fordobling reflekteres af menneskene, således at de konstituerer samfundet som borgere og staten som mennesker.

\section{III}

Forvirringen omkring disse distinktioner er en vigtig grund til forkerte opfattelser af det kapitalistiske samfund og den heraf følgende forkerte politik. Jeg vil nu fremføre et paradigma, som kan forklare dette problem.

Jeg har allerede været inde på, at sammensmeltningen af $\emptyset$ konomi og politik, af bevægelseslove og magt, er karakteristisk for revisionen af Marx' analyse af det kapitalistiske samfund. Denne revision foregik i Tyskland efter $1890 \mathrm{i}$ en periode med en relativt blomstrende kapitalisme. Den vigtigste repræsentant for den tyske revisionisme er Eduard Bernstein, som skriver: »Der findes ingen $\varnothing$ konomisk lov, som foreskriver, hvor mange af de producerede varer samfundets producerende lag skal kunne tilegne sig, og hvor mange de besiddende lag skal tilegne sig som tribut. Fordelingen af den samfundsmæssige rigdom har altid været et spørgsmål om magt og organisation.« 
De $\varnothing$ konomiske love, som Marx analyserede for at forstå den kapitalistiske produktionsmåde, substitueres på denne måde med magtkategorien. Magt er uafhængig af produktionsmådens love og er derfor ikke længere begrænset, men nu en kategori, i hvilken de økonomiske love er ophævet. Derfor vil en styrkelse af arbejdernes magt gøre dem i stand til at forbedre arbejdernes levestandard allerede inden for det kapitalistiske samfund. Kapitalens mulige reaktioner som dette samfunds subjekt reflekteres ikke længere eller reflekteres kun, som om det stammer fra magten.

Denne revision af den marxske teori har politiske konsekvenser, nemlig en amputering af det revolutionære indhold i analysen af kapitalismen. Nu behøver kapitalismen jo ikke længere afskaffes revolutionært for at kunne overskride grænserne for en forbedring af arbejdernes samfundsmæssige situation. Der findes ikke sådanne grænser eller hvis de findes, kan de i hvert fald fjernes gennem magten.

Revisionen bliver mere tydelig, hvis man ser på det argument, som Bernstein forklarer muligheden for lønstigninger med. Lønstigninger er mulige, fordi andre omkostningsfaktorer kan falde. Således undlader han at analysere den vigtige relation mellem arbejder og kapitalist eller løn og profit, og undersøger kun den overfladiske sammenhæng mellem lønomkostninger og andre omkostninger. Han skriver: »Forbedringer af arbejdsprocessen gør det muligt at formindske andelen af levende arbejde i det enkelte produkt, hvorfor en forhøjelse af prisen på menneskeligt arbejde kan blive kompenseret eller endda overkompenseret ved at spare på andre udgifter.« Merværdi og dens former, profit og rente, udelukkes i denne analyse. Lønnen analyseres kun med hensyn til dens sammenhæng med andre omkostnings- og priselementer. Hermed forsvinder antagonismen i den kapitalistiske produktionsproces i omkostningskalkulationens overfladeskær. I omkostningskalkulationen er alle omkostninger kvalitativt ens, og kun forskellige i kvantitativ forstand. Denne kvalitative lighed skjuler det faktum, at kapitalen omfatter kvalitativt forskellige ting, nemlig kapital og arbejde. Det er således denne kvalitative lighed, der gør Bernstein og andre revisionister i stand til at bringe forskellige ting på en klar dimension: magtdimensionen. Den kvalitative forskellighed synes kun at være en kvantitativ ulighed, som kan mildnes eller korrigeres ved en passende politik. Klassekampen tranformeres indholdsmæssigt til en kamp om indkomstfordeling.

Rudolf Hilferding når frem til samme konklusion. Det er meget interessant at summere hans argumentation, fordi den indeholder principielle metodologiske problemer, og fordi det kan vise, hvorledes metodologiske standpunkter får politiske konsekvenser. Hilferding søger en videnskabelig forståelse af de økonomiske fænomener i senkapitalismens udvikling. Disse fænomener omfatter kapitalkoncentration, monopolisering eller kort sagt: finanskapitalens opståen. Han rejser herefter spørgsmålet om disse historiske manifestationer er særlige udtryk for den kapitalistiske udviklings almene love, eller om de er indikato- 
rer på en ny kvalitet hos kapitalismen. Hilferding rejser selv disse spørgsmål, men hans svar er ikke ensartede. På den ene side skriver han, at hvis man vil identificere forandringerne i erhvervscyklerne, så må man kunne forklare dem teoretisk for at være sikker på, at det ikke kun drejer sig om særlige cykler, som blot svarer til en bestemt fase i kapitalismen; at de altså ikke er tilfældige forandringer, men derimod tendenser, som er resultater af essensen i den kapitalistiske udvikling. Men på den anden side forkynder han, at finanskapitalen forandrer kapitalens karakter i almenhed. Kapital synes at være en ensartet magt, som regerer suverænt overfor samfundets livsproces. Er disse nye fænomener kun udtryk for den kapitalistiske produktionsmådes natur, eller er de nye fænomener udtryk for en ny kapitalisme - finans- eller monopolkapitalismen? Hilferding er ikke i stand til at give et klart svar på dette spørgsmål.

Teoretiske undersøgelser af den kapitalistiske udviklings natur fører ham til at forklare de nye fænomener i den kapitalistiske udvikling som udtryk for kapitalen i almenhed, mens hans betagelse over finanskapitalens nye fænomener, nemlig organisering af produktion og distribution og fremkomsten af store firmaer, fører ham til at tale om muligheden for at organisere kapitalismen og derfor om et nyt udviklingstrin, som er helt forskelligt fra den kapitalistiske konkurrences tidligere udviklingstrin. På denne måde får kapitalismen to forskellige essenser. Den ene er i overensstemmelse med den blinde konkurrences kapitalisme, og den anden korresponderer til monopolkapitalismen med muligheden for at organisere produktion, distribution og konsumtion. Mens krisens blinde lov tidligere regulerede kapitalernes aktioner, er det nu den forbundne bevidsthed hos de store trusters produktionsledere. Trustlederne fordeler produkter og produktion, og på denne måde regulerer og kontrollerer de den kapitalistiske udvikling. Og konsekvenserne: det er nu kun et spørgsmål om magt, om hvem der udøver kontrol og hvem produktionsresultatet tilhører. Man ser, at Hilferding ligesom Bernstein udvisker den kapitalistiske udviklings modsigelser ved at bringe alle modsigelsesfulde elementer på samme dimension - magt og styrke. Denne teori indeholder en meget underlig opfattelse af den kapitalistiske udvikling. På den ene side accepteres den kapitalistiske produktions bevægelseslove som helhed på den måde, Marx formulerede dem. Men i samme øjeblik monopolerne og finanskapitalen opstår, erklæres alle de bevægelseslove for den kapitalistiske produktion, som frembringer monopolet, ugyldige. Det ser ud som om kapitalismen ophører med at være kapitalisme, og især som om kapitalismens bevægelseslove ophører med at være love i de tilfælde, hvor monopoler opstår. Magtkategorien korresponderer med monopolerne, mens bevægelseslovene udelades.

Det er let at vise, at denne reduktion af de $\varnothing$ konomiske modsigelser til magtog styrkedimensioner har meget stor politisk betydning. I sin meget berømte tale på det tyske socialdemokratis kongres i 1927 talte Hilferding om, at den organiserede kapitalisme er en realitet, der som helhed er forskellig fra den gamle konkurrencekapitalisme. Derfor må socialdemokratiet udvikle en ny taktik, der 
er i overensstemmelse med de nye fænomener i den organiserede kapitalisme. Det er et meget væsentligt punkt, når han fremhæver, at menneskene i dag lever i den periode af kapitalismen, hvor den frie konkurrence er forsvundet som blind regulator af markedet og kapitalisternes og arbejdernes handlinger. Nu er den kapitalistiske organisering og planlægning af $\varnothing$ konomien tværtimod blevet en realitet. »En virkelig organiseret kapitalisme betyder en principiel underordning af det kapitalistiske princip om fri konkurrence under det socialistiske princip om planlagt produktion. En planlagt og bevidst styret $\varnothing$ konomi kan muligvis adlyde samfundets bevidste regulering, d.v.s. adlyde reguleringen fra den eneste samfundsmæssige organisation, som er bevidst og stærk nok: statens regulering.«

I dette argument finder Hilferding ikke alene socialistiske principper i de kapitalistiske strukturer, men også, at staten kan overtages af den store masse af arbejdere. Hilferding konkluderer, at det kapitalistiske samfund underlægges den voksende indflydelse fra arbejderklassen mere og mere, og at arbejderklassens politiske princip om at bruge staten som regulerinsmiddel vinder. Men hvorledes skal man så påvirke staten til at handle i overensstemmelse med massen af arbejdere? Svaret er simpelt, og Hilferding giver det selv: »Skabelsen af statens intentioner er intet andet end kombinationen af de mange individers politiske viljer.« Argumentet er meget logisk. Kapitalismen organiserer sig selv, og ved at organisere sig skaber den allerede det socialistiske samfunds principper. Staten er ikke længere den herskende klasses stat, som må bekæmpes for at kunne opbygge et socialistisk samfund, men et apparat, som kan påvirkes af de individuelle vælgeres politiske viljer. Som følge af, at de mange individers store masse i det borgerlige samfund er arbejdere, er det deres opgave at bestemme statens vilje ved at stemme på et parti, som erklærer sig som arbejderparti. Derfor må det være en hovedopgave for socialdemokratiet at oplyse arbejdermassen, således at de stemmer socialdemokratisk. Socialdemokratiet vil være i stand til at give staten vilje i overensstemmelse med arbejdernes interesser.

Når de økonomiske love og modsigelser erstattes af magtkategorier, så må man som en konsekvens spørge om, hvorledes magt konstitueres, og Hilferding svarer, at den konstitueres ved at addere individernes - især arbejdernes - politiske viljer. I denne sammenhæng opfattes forholdet mellem politik og økonomi således: Den politiske vilje, som er sammensat af de mange individuelle viljer, er den samfundsmæssige udviklings subjekt, mens den organiserede $\emptyset$ konomi hele tiden er dens objekt. Arbejderklassen må kæmpe for at erobre statens koncentrerede politiske vilje ved hjælp af stemmer og oplysning.

Statens rolle under kapitalismen reflekteres på en anden, men ikke mindre problematisk måde i teorierne om den statsmonopolistiske kapitalisme. Et argument er typisk for alle teorier om STAMOKAP, selv om de er forskellige på mange andre vigtige punkter. De fremhæver, at koncentrationen af kapitalproduktionen fører til en situation, hvor konkurrencen er elimineret, således at regulatoren af produktion og distribution også sættes ud af kraft. Følgen af konkurrencens 
forandring til monopolistisk konkurrence er også, at det er umuligt at regulere produktionen rationelt. D.v.s. at kapitalismen selv er ude af stand til at regulere produktion og distribution i sit sidste stadium. Derfor må der være en anden institution, som kan overtage de funktioner, som konkurrencen udfyldte tidligere.

Denne institution må være staten, som nu intervenerer systematisk i økonomien. Monopolet $\varnothing$ delægger konkurrencen som den kapitalistiske udviklings regulerende princip, men monopolet frembringer også en ny regulerende institution, staten, som indgår i en enhed med monopolet: monopol og stat smelter sammen i den statsmonopolistiske kapitalisme.

Monopolernes ophævelse af de økonomiske love fremtvinger interventioner fra statens side, d.v.s. interventioner af den politiske magt - eller som en repræsentant for STAMOKAP-teorien, Peter Hess, udtrykker det: »Den $\varnothing$ konomiske og ikke- $\varnothing$ konomiske magt bliver eksekutor af de $\varnothing$ konomiske love på grund af det forhold, at værdilovens regulerende evne er sat ud af kraft ved koncentration, centralisering og monopolisering. « Monopol, magt og stat er således de tre kategorier, som STAMOKAP-teorierne bygger på. Denne anvendelse af magtkategorien fører tilbage til det eksempel, som er anført i begyndelsen. Som en relation mellem magt og styring er det monopolets mål at tilegne sig fremmed kapital, fremmed profit, fremmed ejendom og derfor fremmed arbejde. Det er klart, at denne tilegnelse af revenu ikke alene kommer fra en direkte udbytning af arbejderne, men netop implicerer mere end det. Derfor erstattes profitkategorien med tributkategorien. Således ser man her - på et andet plan at repræsentanter for STAMOKAP-teorierne drager en konklusion, der ligner Hilferdings. Men nu er det ikke længere klart, hvorledes monopoltributterne produceres og fordeles, og det er heller ikke klart, hvilke grænser de er underlagt og hvilke samfundsmæssige modsigelser og konflikter, der følger af denne udplyndring af hele samfundet. I modsætning til teorien om monopoltribut og denne kategori, følger profitbegrebet visse love med hensyn til profittens dannelse og udvikling, som er udtrykt i teorien om dannelsen af en gennemsnitlig profitrate og den gennemsnitlige profitrates tendens til fald.

Før vi kan gå ind på en diskussion af statens rolle under monopolkapitalismen, må vi betragte relationen mellem monopol og bevægelseslove. Hvis der også er bevægelseslove under monopolistiske betingelser, så må der være grænser for den statsmonopolistiske intervention, og omvendt: hvis der ikke findes bevægelseslove, vil det være absurd at tale om grænser for statens handlinger under STAMOKAP.

\section{IV}

Vi skal først skelne mellem to aspekter ved det kapitalistiske samfunds bevægelseslove. Der er dels de væsentlige bevægelseslove for produktionsrelationerne og dels bevægelseslovenes gennemslagsformer i den samfundsmæssige realitet. Konkurrencen betragtes som bevægelseslovenes gennemslagsform, og 
hvis konkurrencen afskaffes, vil bevægelseslovenes gennemslag blive forhalet og forandret.

Vi skal nu betragte et særtræk ved den marxske teori. I alle de tilfælde, hvor Marx taler om bevægelseslove, antager han, at disse bevægelseslove omfatter den samfundsmæssige totalkapital og ikke ubetinget enhver enkeltkapital. Men på den anden siden eksisterer denne samfundsmæssige totalkapital i form af mange enkeltkapitaler. Enkeltkapitalerne, og ikke den samfundsmæssige totalkapital, er agenterne i samfundet. Man må således forestille sig, at de mange enkeltkapitalers handlinger konstituerer det, som kan kaldes den samfundsmæssige totalkapital, som bevægelseslovene korresponderer med. Denne relation mellem enkeltkapital og samfundsmæssig totalkapital konstituerer det, som så ofte kaldes den kapitalistiske udviklings anarki eller spontanitet. Ingen enkeltkapital kender det nøjagtige resultat af sine handlinger. Men gennem deres handlinger, konstituerer enkeltkapitalerne den samfundsmæssige totalkapital og bestemmer kapitalismens udviklingsmåde. Heraf følger, at alle enkeltkapitaler er brøkdele af den samfundsmæssige totalkapital. Det stærkeste udtryk for denne relation er, at enhver enkeltkapital ikke får mere end den gennemsnitlige profitrate, d.v.s. at den får sin profitandel af den totale producerede merværdi i forhold til sin egen størrelse. Dette er meget vigtigt, fordi det betyder, at hvis nogle enkeltkapitaler er i stand til at få mere profit end andre, så er de i stand til at unddrage sig de betingelser, som sættes gennem bevægelseslovene for den samfundsmæssige totalkapital. Nu kan man indvende, at det i den kapitalistiske realitet er helt normalt, at nogle enkeltkapitaler får mere profit end andre og omvendt, samt at der ikke findes en gennemsnitsprofitrate for alle enkeltkapitaler. Og denne indvending er helt korrekt. Dannelsen af gennemsnitsprofitraten kan nemlig kun forstås som en tendens, ikke som en realitet på ethvert tidspunkt. Men denne tendens må dog realiseres, i hvert fald indenfor den industrielle cyklus. Hvis der findes enkeltkapitaler, som er i stand til at unddrage sig den tendentielle dannelse af gennemsnitsprofitraten for en meget langt periode, er de ikke længere elementer i den samfundsmæssige totalkapital. Denne antagelse forekommer mig at give den $\varnothing$ konomiske betydning af argumentet om monopolet som en relation mellem magt og styring eller den ikke- $\varnothing$ konomiske magt, som den monopolistiske konkurrence bygger på. Hvis monopolspørgsmålet forstås på denne måde, er monopolet kun et spørgsmål om tid: hvor længe er en enkeltkapital i stand til at unddrage sig tendenser til dannelse af en gennemsnitsprofitrate, samt omvendt hvor længe varer det før konkurrencen har bragt monopolprofitten på gennemsnitsprofitratens niveau?

Det vil selvfølgelig være absurd at benægte, at der er forskelle i enkeltkapitalernes profitrater, men det vil være lige så absurd at gå ud fra en antagelse om, at der altid må være et hieraki af profitrater. Dette ville nemlig være i modstrid med opfattelsen af kapital som et samfundsmæssigt forhold, som må forstås både kvalitativt og kvantitativt. Kvalitativt omfatter kapital forholdet mellem kapital 
og arbejde og derfor kapitalens udbytning af arbejderklassen. Hele den profit, som fordeles mellem enkeltkapitalerne, er skabt af arbejderklassen i et land, henholdsvis arbejderklassen i international forstand. Dette kvalitative forhold mellem kapital og arbejde som en helhed, fremstår kvantitativt for hver enkeltkapital, fordi profitraten er et kvantitativt mål, hvormed kapitalen måler sin realisering som vækst i dens størrelse (værdiens selvvalorisering, »selbstverwertung des Wertes«). Kapitalen kan kun eksistere videre som en kvalitativ relation, hvis den kvantitativt udtrykte profitrate er stor nok. Dette betyder, at den kvantitative vækst i enkeltkapitalens størrelse er en betingelse for, at kapitalen kan opretholde sig som en kvalitativ relation. Hvis der i en længere periode eksisterer enkeltkapitaler med en meget lav profitrate og andre enkeltkapitaler med en meget høj profitrate (monopoler) vil det nødvendigvis betyde, at kapitalforholdet som et kvalitativt forhold vil blive berørt af disse kvantitative forskelle. Denne dialektik mellem kvantitet og kvalitet under monopolistiske betingelser har endnu en konsekvens. Hver enkeltkapitals mål er at opnå en så stor profit som muligt, hvilket kvantitativt er i modsætning til enhver anden enkeltkapitals mål. Kapitalens realisering er altid begrænset af den udbyttelige arbejdskrafts størrelse, af arbejdsdagens længde, af arbejdsintensiteten, af lønforhøjelser og sidst, men ikke mindst, af arbejdets produktivkraft. Derfor vil konkurrencen også forekomme selv under monopolistiske betingelser. Enhver enkeltkapital konkurrerer med de andre om den udbyttelige arbejdskraft, om forøgelser af arbejdsproduktiviteten o. s. v. I denne forstand er muligheden for en kvantitativ profitforøgelse begrænset af det kvalitative forhold mellem kapital og arbejde. Man kan altså konkludere, at konkurrencen ikke alene regulerer enkeltkapitalernes indbyrdes forhold, men også forholdet mellem kapital og arbejde. Når man teoretisk taler om modificeringen af værdiloven eller endda dens ophævelse under monopol- og statsmonopolkapitalisme, proklamerer man følgelig også ophævelsen af kapitalismen som samfundsmæssigt system. Vi har allerede set, at Hilferding drog denne konklusion ret logisk ved at betragte den organiserede kapitalisme som et helt nyt system i forhold til den gamle kapitalisme med en fri eller ubegrænset konkurrence. Hvis værdiloven er ophævet eller blot modificeret, må der selvfølgelig være andre love og grænser for statsinterventionerne, end det ville være tilfældet, hvis der fandtes bevægelseslove for den kapitalistiske udvikling.

V

Hvorledes forholder den frie konkurrence sig til den monopolistiske konkurrence.

Som regel bestemmes monopolet ved at være i stand til at opnå en monopolprofit. Den frie konkurrence fører derimod til, at de enkelte profitrater udlignes til en samfundsmæssig gennemsnitsprofitrate. I monopolet findes denne tendens ikke. Denne opfattelse er fælles for såvel borgerlige som marxistiske teoretikere. Man kan citere Heiniger/Hess: »Den monopolistiske konkurrence hviler på anvendelse 
af $\varnothing$ konomisk og ikke- $\varnothing$ konomisk magt og vold med den hensigt at producere og realisere monopolprofit - dette er den afgørende forskel fra den førmonopolistiske frie konkurrence. I og med at monopolet ophæver den frie konkurrence, undergraver det også den mekanisme, som hviler på gennemsnitsprofitter - den mekanisme, der fik den enkelte producent til spontant at handle i overensstemmelse med de $\varnothing$ konomiske love og som medførte en fordeling af profitten i overensstemmelse med kapitalstørrelsen. I stedet for den frie konkurrence og ved siden af den træder netop monopolernes $\varnothing$ konomiske magt og vold. Denne træder nu overfor producenterne, og den gør den kapitalistiske produktionsmådes indre lovmæssigheder gældende overfor producenterne som tvangslove til handling. Den $\varnothing$ konomiske og ikkeøkonomiske magt og vold bliver de økonomiske lovmæssigheders 'eksekutor'. Man behøver vel næppe at betone, at dette intet har at gøre med absolutte monopolvilkår i det $\varnothing$ konomiske område... « (s. 34 i Imp. der BRD).

Men man må selvfølgelig spørge om I) hvorfra stammer monopolprofitterne og II) om og hvordan de indgår i gennemsnitsprofitratens udligningsproces.

Mht. første spørgsmål om hvorfra monopolprofitterne stammer, er der principielt 4 muligheder:

1) Monopolistiske profitter er ene og alene ekstraprofitter, fremkommet ved det forhold, at de monopolistisk frembragte eller producerede varers individuelle værdi ligger under deres samfundsmæssige værdi eller under branchens markedsværdi, hvorfor der kan opnås en ekstraprofit.

2) Monopolprofitterne stammer fra den ikke-monopoliserede sektor og er kun overførte vardidele fra denne sektor.

3) Monopolprofitterne stammer fra en overgennemsnitlig udbytning af arbejderne, uanset om denne udbytnings form er sænkning af arbejdskraftens pris under dens værdi eller en overgennemsnitlig arbejdsintensitet eller arbejdstid. Monopolprofitterne kunne da kaldes 'løntyveri'.

4) Monopolprofitterne kan også forklares ved at de eksisterende kapitaler omfordeles til fordel for monopolerne, d. v. s. at den eksisterende kapitalstok i en periode går over til monopolerne, således at monopolprofitterne ikke er begrænsede af den samlede merværdimasse.

Man må vide hvorfra monopolprofitterne stammer, eftersom svaret på dette spørgsmål også indeholder svaret på det andet spørgsmål, altså om en totaløkonomisk gennemsnitsprofitrate også kan udvikles under monopolbetingelser. Her må vi dog minde om to tilsyneladende simple sammenhænge.

A). I gennemsnitsbegrebet og i gennemsnitsprofitraten er det samfundsmæssige moment indeholdt, det moment, som alle enkeltkapitler og kapitalen som totalkapital er underlagt. Trods de individuelle forskellige produktionsbetingelser frembringer kapitalen både gennemsnitlige udbytningsbetingelser, som udvikles som en gennemsnitlig merværdirate (det er derfor ikke kun en forsimplende antagelse i Kapitalens 1. bog, hvor Marx går ud fra en fælles gennemsnitlig merværdirate på 100) og samtidig udtrykkes i gennemsnitsprofitraten 
enhver enkeltkapitals deltagelse i den merværdimasse, der er frembragt af den totale samfundsmæssige arbejderklasse, i overensstemmelse med sin størrelse.

Hvis man nu går ud fra, at der findes to gennemsnitsprofitrater - den normale og den monopolistiske - må man som konsekvens heraf også gå ud fra, at der under monopolistiske produktionsbetingelser findes to kapitalistiske »subsamfund « indenfor det kapitalistiske samfund: et, hvor loven om udligning af ekstraprofitter gælder, og et, hvor loven om gennemsnitsprofitraten gælder uden resp. med fradrag for ekstraprofitterne. Eller med andre ord: en del af samfundet, hvor loven om udligning ikke kan virke og en anden, hvor den kan virke.

Foreløbig betyder dette dog ikke andet end, at lovmæssighederne for kapitalen i almenhed vil gælde for hele det kapitalistiske samfund, mens den form, som disse lovmæssigheder sætter sig igennem i, kan være forskellige og endda modstridende.

Formidlingen mellem disse to samfund indenfor et og samme kapitalistiske samfund sker ved, at der foregår værdioverførelser fra den ikke-monopoliserede sektor til den monopoliserede, og herved findes grænserne for begge samfunds totale profitmasse i størrelsen af den totale af arbejderklassen frembragte merværdimasse. Alligevel er en sådan antagelse om eksistensen af to forskellige gennemslagsformer for de kapitalistiske lovmæssigheder i et land i en bestemt tidsepoke en vidtrækkende opgivelse af værdiloven og dermed også en opgivelse af den marxske teori. Dette skyldes, at værdiloven omfatter både den kapitalistiske produktions immanente nødvendigheder og gennemslagsformen for disse immanente nødvendigheder. Man kan ikke se det ene uden det andet.

»Da nu varernes totalværdi bestemmer totalmerværdien, mens denne så igen bestemmer gennemsnitsprofittens højde og dermed den almene profitrate - som almen lov, d. v. s. som det, der behersker svingningerne - så regulerer værdiloven produktionspriserne.« (3:1, s. 233). Alle andre antagelser om ikke eksisterende gennemsnitsprofitrater overser vanskelighederne ved så at skulle forklare, hvilke udligningslove, der nu gælder.

$B$ ). Antagelsen om de to profitrater resp. om en gennemsnitsprofitrate og mange individuelle monopolprofitrater kan implicere, at den gennemsnitsprofitrate som Marx udledte for den »frie« konkurrence, skulle eksistere som sådan »ansich« på ethvert tidspunkt.

Men gennemsnitsprofitraten er langt snarere på enhvert tidspunkt de mange enkeltkapitalers gravitationscentrum. Den er aldrig en virkelig gennemsnitsprofitrate, men en tendens, som alle kapitaler bevæger sig hen mod.

»I den kapitalistiske produktion er det i det hele taget altid sådan, at den almene lov kun gør sig gældende som herskende tendens på en yderst kompliceret og tilnærmet måde, som et aldrig fastslået gennemsnit af stadige svingninger.«:3:1, 209).

Set i dette lys er forskelligheden i den monopoliserede og ikke-monopoliserede sektors profitrater ikke noget særligt i forhold til den »frie« konkurrence. 
Det, som egentlig skulle begrundes, er varigheden af de enkelte kapitalers mulighed for at opnå ekstraprofitter uden, at muligheden forsvinder igen.

Fritz Behrens har set denne sammenhæng: »Da kapitalernes konkurrence om investeringssfærer ikke er ophævet, men kun hæmmet, følger det også, at disse monopolprofitrater også har en tendens til at udlignes; men denne tendens virkeliggфres nu ikke langere som $i$ den førmonopolistiske kapitalisme $i$ lobet af en enkelt cyklus. « (Behrens i »Bemerkungen zur Profitrate im monopolistischen Kapitalismus, « i: Wirtschaftswissenschaft, 5. Jahrg. 1957 s. 256).

Det ville ikke føje noget nyt til Marx' fremstilling af gennemsnitsprofitratens udvikling, men nok være en modifikation, hvis man kunne begrunde, at udviklingen af ekstra-profitter ikke ubetinget må forekomme inden for en og samme cyklus, men kan foregå gennem flere cykler, betinget af statens funktioner og verdensmarkedssammenhængen.

Men lad os nu vende tilbage til de fire fundamentale muligheder for monopolprofittens opstån.

Ad 1: Ekstraprofit pga. forskellen mellem markedsværdi og individuel værdi.

Kapitalernes indbyrdes relationer indenfor en branche fører via konkurrencen til markedsværdiens opståen. En given vares gennemsnitlige produktionsbetingelser bestemmer dens samfundsmæssige værdi (markedsværdien), som de enkelte vareproducenters individuelle produktionsværdier kan afvige fra. De gennemsnitlige produktionsbetingelser skal forstås som de typiske, altså den store masses produktionsbetingelser, og ikke som en fiktiv regnestørrelse med et fiktivt gennemsnit af indbyrdes afvigende produktionsprocesser. Hvis enkelte kapitaler, producerer under de samfundsmæssigt gennemsnitlige produktionsomkostninger på grund af en bedre teknologi, d. v. s. hvis deres kostpris er lavere end den samfundsmæssige, så vil de opnåen tillægsprofit ud over den normale, en ekstraprofit. Denne ekstraprofit fremkommer ikke i kraft af værdioverførsel fra andre brancher eller kapitaler, men udelukkende på grund af forskellen mellem individuel og samfundsmæssig værdi.

Indenfor en branche findes der derfor på ethvert givet tidspunkt forskelle $\mathrm{i}$ de profitrater, som de enkelte kapitaler opnår, forskelle, som dog altid opløses gennem konkurrencen, hvor de også genskabes.

Den bedre produktionsteknologi, som gør det muligt for en enkelt kapital at sænke den individuelle vares værdi under dens markedsværdi, giver denne enkeltkapital en midlertidig monopolstilling i og med at den muliggør opnåelsen af en monopolprofit i form af ekstraprofit. De behøver ikke nødvendigvis at være de største kapitaler, der får denne ekstraprofit, men kan i vidt omfang også være mindre kapitaler, der udfører eksperimentel produktion med avanceret produktionsteknologi. Dette forhold må tages med i betragtning for ikke at falde for den gængse misforståelse, at monopolerne er lig store koncerner og ikke-monopoler er lig mindre og mellemstore foretagender. Det kan omvendt endda være tilfældet, at de store foretagender ikke er tvunget til at indføre en 
ny teknologi for at opnå ekstraprofitter, fordi de er store nok til at udnytte deres finanskraft så meget, at de helt kan undgå de ricisi, der er forbundet med indfrielsen af den nye produktionsteknologi.

Spørgsmålet bliver nu, om ekstraprofitter, der er opstået som en følge af forskellen mellem individuel værdi og markedsværdi, kan være vedvarende - altså udgøre en permanent monopolprofit ud over den almindelige profit. Det kan den kun hvis følgende to betingelser er opfyldt:

a). Hvis det kan lykkes for den kapital, der er i stand til at opnå en ekstraprofit på denne måde, at fastholde sit teknologiske forspring. Dette kan ske ved at enhver teknologisk udvikling hos de andre enkeltkapitaler i samme branche blokeres.

b). Eller hvis det teknologiske forspring opretholdes ved at den teknologiske fornyelseshastighed er mindst lige så stor som hos konkurrenterne - de efterfølgende kapitaler, der producerer varer til samfundsmæssig værdi.

Tilfælde a) ville implicere en standsning i den teknologiske udvikling og en cementering af et givet teknologisk niveau.

Tilfælde b) ville implicere det modsatte, nemlig en progressiv forøgelse af den teknologiske fornyelse.

Begge tendenser er således virksomme, og netop herfra stammer de store koncerners vaklende og modsigelsesfulde teknologipolitik: dels opretholdelse af meget store forsknings- og udviklingsafdelinger, både absolut og relativt, som der anvendes meget kapital til. Herfra kommer der nye produkter, ny teknologi og nye produktionsmetoder m.v. Dels også en forsegling af den teknologiske erkendelse gennem patentering, fabrikationshemmeligheder o.s.v. for at forhindre andre kapitaler i at få viden om ekstraprofittens årsag i en specifik produktionsteknologi. Herved hindres den nye teknologis udbredelse, og udligningen mellem varernes samfundsmæssige værdi og de mest avanceret producerede varers individuelle værdi vanskeliggøres. Men teknologiens udbredelse og hermed ekstraprofitternes afskaffelse kan dog ikke forhindres helt, eftersom det ikke kun er kapitalerne indenfor en og samme branche, der indgår i udligningsbevægelsen. Den foregår jo netop over produktionsprisen, d.v.s. over konkurrencen mellem brancherne. D.v.s. at de kapitaler, der er udlagt i andre brancher med en lavere profitrate end den avancerede kapital, som vi betragter her, også indgår i denne formidlingsbevægelse.

Sammenfattende kan vi altså sige, at her viser det sig, at de udligningsbevægelser, som Marx har formuleret, fortsat er virksomme, men nu nok over et længere tidsrum end under den »frie« konkurrence.

ad 2) Profitoverførsel fra den ikke-monopoliserede sektor. Enkeltkapitaler har kun andel i den af arbejderklassen producerede merværdimasse som bestanddele af den samfundsmæssige totalkapital, uanset hvor store de måtte være. Men da enkeltkapitalernes produktionsbetingelser er forskellige, især med hensyn til organisk sammensætning og omslagstid, ville den opnåede pro- 
fitrate være forskellig, selv under antagelse af samme merværdirate, hvis der ikke forekom værdioverførsler mellem kapitaler i forskellige brancher. Dette betyder, at der allerede i gennemsnitsprofitratens udligningsproces $n \phi d v e n d i g$ vis må finde vardioverførsler sted under den frie konkurrences betingelser. Ellers ville der nemlig slet ikke findes nogen gennemsnitsprofitrate.

Når man således taler om monopolernes ekstraprofit, opstået gennem værdioverførsel fra den ikke-monopoliserede sektor, må det altså være merværdioverførsler, som ved denne overførsel medvirker til en udligning af profitraten, altså til gennemsnitsprofitratens opståen. For den ikke-monopoliserede sektor betyder dette, at dens gennemsnitlige profitrate må være lavere end den ville være, hvis den monopoliserede sektor ikke fik en vedvarende monopolistisk ekstraprofit.

Spørgsmålet bliver så, om monopolerne kan gøre disse profitrateforskelle vedvarende? Når vi ser bort fra verdensmarkedskonkurrencen, kan det ikke lade sig gøre af følgende grunde:

a) Hvis monopolernes profitrate ligger betydeligt over de ikke-monopoliserede kapitalers profitrate, vil udligningsprocessen virke over kort eller lang tid derved, at de kapitaler, som har en langt lavere profitrate, bevæger sig ind i den monopoliserede sektor for at akkumulere her. »Kapitalen trækker sig imidlertid ud af en sfære med lavere profitrate og kaster sig over andre, der afkaster højere profit. Som følge af denne bestandige af- og tilgang, kort sagt, som følge af hvorledes kapitalen fordeler sig på de forskellige sfærer, alt efter om profitraten falder det ene sted og stiger det andet, fremkalder den et sådant forhold mellem udbud og efterspørgsel, at gennemsnitsprofitten indenfor de forskellige produktionsfærer bliver den samme og værdierne derfor omdannes til produktionspriser.« (3:1, s. 253-4) Monopolerne kan måske nok spærre for denne udligningsproces en vis tid, men på langt sigt vil det ikke kunne lykkes hvis profitforskellen er store nok til at lokke mængder af akkumulationsduelig kapital til disse højprofitable sektorer, formidlet gennem finanskapitalen.

b) Lad os nu betragte processen fra den anden side: Også i monopolkapitalismen virker konkurrencen på den måde, at kapitaler koncentreres, fusioneres og centraliseres. Denne tendens er egenartet for den kapitalistiske akkumulation, hvilket Marx har vist i Kapitalens bind 1 kap 23. Men når koncentrationsog centraliseringsprocessen griber ind over den ikkemonopoliserede sektor, således at små kapitaler sluges af monopolerne, må deres lavere profitrate også udtrykke sig i en forringelse af monopolernes profitrate, for så vidt som monopolernes ekstraprofitter fremkommer gennem værdioverførsel fra den ikkemonopoliserede sektor. I det ekstreme tilfælde vil monopolernes ekstraprofitter forsvinde, når hele den ikke-monopoliserede sektor er opslugt af monopolerne. Denne tendens er også virksom, hvilket fremgår af, at monopolerne ikke kan akkumulere deres profitmasse inden for deres egen branche, hvorfor de har meget store mængder kapital, som søger investeringssfærer. De kan ikke akkumulere deres profitmasse indenfor deres egen branche af hensyn til oprethol- 
delsen af deres monopolstilling d.v.s. for ikke at true deres monopolprofitter og monopolpriser.

Når man påstår, at tendensen til koncentration og centralisering virker samtidig med muligheden for monopolistiske ekstraprofitter gennem værdioverførsel, bevæger man sig ind i en immanent modsigelse, som kun kan løses ved at man ikke længere kan benægte, at udlignigstendenserne fører til dannelsen af en totalsamfundsmæssig gennemsnitsprofitrate.

Her er det også klart, at udligningstendenserne virker over længere tidsperioder end under den »frie« konkurrence.

ad 3) Monopolekstraprofitter som følge af sænkning af prisen på varen arbejdskraft.

Forsøget på at sænke arbejdskraftens pris under dens værdi er ikke særegent for monopolkapitalismen. Det har netop kendetegnet den »frie « konkurrences epoke, hvilket arbejderklassens historie tydeligt viser. Metoderne til denne sænkning er lige så gamle som selve den kapitalistiske udbytning: løntryk, for$\emptyset$ gelse af arbejdstiden uden lønstigning, større arbejdsintensitet, salg af nødvendige konsumvarer til en pris over deres værdi, hvorved reallønnen trykkes nedad o.s.v. Lykkes disse forsøg på sænkning af arbejdskraftens pris, bliver resultatet en forøgelse af merværdiraten for alle kapitaler, og ikke en forøgelse af monopolprofitten for den monopoliserede sektor. Og her kommer vi til det kritiske punkt i monopolprofitteorien. Man går ikke alene ud fra, at gennemsnitsprofitraten ikke længere er gyldig, hvorfor der sker en opdeling i en monopolprofitrate og en ikke-monopolprofitrate, men man går endda også ud fra, at de gennemsnitlige udbytningsbetingelser $i$ et givet nationalt samfund ikke længere gælder, d.v.s. at man går ud fra, at monopolkapitalens mervardirate er større end merværdiraten i den ikke-monopoliserede sektor. Denne antagelse er under alle omstændigheder i modstrid med lønarbejderens frihed til selv at vælge sin arbejdsplads, hvilket er konstituerende for selve kapitalforholdet. Kun hvis arbejdskraftens mobilitet enten ikke er frembragt endnu eller indskrænket af andre grunde, kan man gå ud fra, at monopolprofitterne stammer fra værdi- eller prissænkning på varen arbejdskraft.

ad 4) Monopolprofitter gennem nyfordeling af de eksisterende kapitaler til monopolernes fordel.

Denne form for overførsel vedrører selve kapitalens substans og kan netop af denne grund kun være forbigående. Men alligevel må den tillægges stor betydning. Den historiske erfaring har vist, at ekspropriationen af små og mellemstore kapitaler til fordel for monopolerne rent faktisk har foregået og i begge verdenskrige foregår især i perioder med stor inflation, frem for alt nu med den gallopperende inflation. Her ligger en kilde til monopolprofit, som dog kun springer, når andre betingelser også er opfyldt, d.v.s. især når staten tager monopolernes parti i denne proces og først rigtig kaster ved på inflationens bål i form af optagelse af statslån for så at ekspropriere den lille kapital eller sparerne. 


\section{Forelфbig sammenfatning}

Der findes ingen $\varnothing$ konomisk mekanisme, der sørger for, at monopolerne vedvarende kan opnå en ekstraprofit i forhold til den ikke-monopoliserede sektor.

De to første former tillod kun midlertidige monopolstillinger, omend monopolstillingens varighed er større i den udviklede kapitalisme end i den svagt udviklede.

Den tredje form for ekstraprofit tilfalder alle kapitaler, monopolform eller ej.

Den fjerde form muliggør ganske vist monopolekstraprofit, men kun midlertidig, eftersom den - hvis den forudsættes at fortsætte fremover - vil ødelægge $\emptyset$ konomiens substans på langt sigt, hvorfor de således opnåede monopolprofitter ikke vil kunne akkumuleres umiddelbart. De vil kun kunne akkumuleres under monopolkapitalens ejendomstitel, ikke i dens reale udbytningsproces.

Dermed har vi også givet - implicit - et svar på det andet spørgsmål, nemlig om monopolprofitterne indgår i udligningsprocessen? Fred Oelssner anfører fire former for stillingtagen til dette spørgsmål, som skal anføres her (i: Probleme der politschen Ökonomie, Bd. 3, Berlin 1960, s. 70ff.).

Den første gruppe mener, at loven om gennemsnitsprofitraten fortsat virker. Dens gennemslag er ganske vist vanskeliggjort, men i sidste ende realiseres en ensartet samfundsmæssig gennemsnitsprofitrate.

Den anden gruppe taler om to forskellige profitrater, nemlig en for den monopoliserede og en for den ikke-monopoliserede del af økonomien.

Den tredje gruppe taler om, at gennemsnitsprofitraten kun kan udvikles for den ikke-monopoliserede del af økonomien, mens den ikke kan opstå for den monopoliserede sketor.

Den fjerde gruppe afviser, at man overhovedet kan tale om gennemsnitsprofitrate under monopolkapitalismen, eftersom den modsiger monopolkapitalismens væsen.

Oellsner slutter sig selv til den 3. gruppe med følgende begrundelse: »Tesen om monopolgennemsnitsprofitrate lader sig med andre ord ikke fastholde teoretisk, fordi monopolernes $\varnothing$ konomiske magt er meget forskellig og fordi, som Mendelson rigtigt anfører, der ikke findes eller kan findes 'en lov for en ligelig fordeling mellem alle monopoler af Gründergevinst, differentialrente og profit som følge af svig med statsejendom ved udplyndring af kolonierne o.s.v.' Men selv når man ser bort fra disse faktorer og kun betragter varemonopolet og monopolprisen for varer, kan der alligevel ikke findes en gennemsnitsprofitrate for monopolprofitten, fordi den gamle frie konkurrence ikke hersker blandt de monopolistiske industri- og handelsvirksomheder, men derimod monopolkonkurrencen. Til forskel fra den frie konkurrence er den monopolistiske konkurrence i høj grad ujævn.«(Behrens, s. 76).

Alt ialt er det kun den første gruppe med den anførte modifikation der kan begrundes i den marxske teori. Netop modifikationen - at gennemsnitsprofit- 
ratens udligning først sker over flere lange cykler - vil sikkert vise sig at være meget vigtig ved analysen af mere afgrænsede historiske perioder.

\section{VI}

Vi skal nu diskutere statsaktiviteterne og forsøge at påvise grænserne for statsaktiviteter under monopolistiske forhold. Der er fire gode grunde til antagelsen om begrænsede statsaktiviteter:

1) statsaktiviteterne betales ud af det producerede revenu, og finansielle midler er derfor altid bundet til den proces, der frembringer revenuet, d.v.s. til kapitalens akkumulationsproces.

2) statsinterventionens instrumenter stammer fra den kapitalistiske $\varnothing$ konomis struktur og må derfor være lige så selvmodsigende som denne økonomi. Statshandlingernes suverænitet $\varnothing$ delægges af, at instrumenterne er for begrænsede til at styre samfundsmæssige processer.

3) Betydningen af samfundets klassestruktur, omfanget af særlige traditioner, den herskende klasses såkaldte politiske kultur, mm. Alle disse mere sociologiske betingelser for statsindblanding er forhindringer for staten, når den skal gribe ind på den måde, der er nødvendig.

4) Statens karakter af nationalstat betyder, at statsinterventioner kan påvirkes af verdensmarkedet, af andre nationalstaters modsat rettede politik og af kapital- og varecirkulationens gensidige afhængighed.

Disse fire årsager må dog forklares mere udførlig.

Man kunne sige, at statsinterventionens grænser skyldes den såkaldte »finanskrise«, som er et strukturelt karakteristikon ved den moderne kapitalisme. Empiriske forhold alene forklarer intet. Af den grund må vi undersøge to forhold som er relevante indenfor rammerne af denne diskussion. Det ene forhold er statens finansielle kilder, og det andet drejer sig om statens anvendelse af finanserne.

I denne sammenhæng støder vi på et ret alvorligt problem. På det kapitalistiske samfunds overflade er enhver ligeså lige og fri som sin nabo, og det fremtræder derfor som om alle betaler til de offentlige indtægter ved at betale skatter og ved at bære en del af nationalgælden. Da enhver borger får et revenu, som kun varierer kvantitativt, trækker staten sine indtægter fra individernes. Det ser således ud som om alle behandles ens også m.h.t. skattebetaling. Men på den anden side ved vi, at det kun er på overfladen, at det kapitalistiske samfund er dannet af lige individer, mens det i virkeligheden er et samfund delt i to klasser, kapitalister og arbejdere. Staten udskriver ganske vist sine skatter fra de skatte-betalende undersåtter, og i denne sammenhæng forsvinder distinktionen mellem arbejder og kapitalist. Men det forhold, at disse skatter er pålagt særskilte klasser og at de er fradrag fra særlige indtægter - løn på den ene side og profit på den anden - gør, at disse skatter har forskellige økonomiske følger, afhængig af om de er trukket fra løn eller profit.

Skat på løn er naturligvis begrænset af de fornødenheder der medgår til arbejdskraftens reproduktion, som igen er afhængig af fysiske, historiske og kulturelle 
betingelser samt af arbejderklassens politiske styrke. De kan derfor ikke overskride en vis, historisk given størrelse. Men denne bestemmelse forbliver upræcis så længe det ikke er forklaret, hvad arbejdernes indtægter og statens udgifter bruges til. Dette skyldes, at alle de statsudgifter, der kun er en omfordeling, forbliver en del af arbejderklassens indtægter og arbejdskraftens reproduktionsmidler. I denne situation er det lige meget om arbejdskraftens reproduktion sker gennem individuel løn-indkomst eller gennem statsudgifter, kaldet »kollektiv indkomst«, til uddannelse af arbejdskraft, sundhedstjeneste, sociale sikringssystemer, o.s.v. Det betyder intet, om disse fornødenheder til arbejdskraftens reproduktion udfyldes af individuel løn eller af statsudgifter der stammer fra skat på individuel løn. Dette er udelukkende et problem om at fordele risikoen mellem arbejderne.

Ved diskussionen af dette problem er det blevet tydeligt, at skatters $\varnothing$ konomiske følger på ingen måde er uafhængig af den måde, de er fremkommet på. Men samtidig bliver det indlysende, at en forøgelse af enten lønnen eller statens udgifter til arbejdskraftens reproduktion resulterer - alt andet lige - i en vækst i arbejdskraftens værdi med den følge, at merværdien formindskes. For vores problem om grænser for statsfinansiering får det følgende konsekvens:

Effekten på merværdien af de stigende udgifter til reproduktion af arbejdskraft hæmmer deres vækst udover et vist punkt.

Lad os nu unders $\varnothing$ ge et andet eksempel. Statsudgifter anvendes til $»$ produktionens generelle forudsætninger«, sædvanligvis kaldt infrastruktur. Som produktionens forudsætninger er de nødvendige for hver enkelt kapitals produktionsproces. Dette gælder for veje, jernbaner, luftfart, vandforsyning samt kompensation for miljøkriser, dræning og et fungerende kommunikationssystem (post, telegraf o.s.v.). I disse tilfælde er statsinterventionens selvmodsigende karakter åbenlys. Disse udgifter er på den ene side nødvendige i bogstavelig forstand udfyldende under hensyn til den materielle side af værdien og kapitalens produktionsproces. Disse udgifter må på den anden side pålægges kapitalistklassen som helhed under den antagelse, at arbejderklassen ikke modtager mere end det, som er nødvendigt for reproduktion af dens arbejdskraft.

Det er således tydeligt, at udlæg til infrastruktur er fradrag i merværdien. Under den realistiske antagelse at kapitalistklassens komsumtion er ret konstant, er der tale om fradrag i den del af profitten, der var beregnet til akkumulation. Udgifter til opbyggelse af en infrastruktur er nødvendige for den private akkumulationsproces og er samtidig hæmmende for den. Dette eksempel tydeliggør også, at der er ret snævre grænser for statsintervention på grund af en strukturel finanskrise, som ikke kan overvindes indenfor kapitalistiske rammer.

Lad os endelig til sidst unders $\varnothing$ ge et tredie eksempel. Vi antager at staten fungerer som enkeltkapital, tager initiativer som en kapitalistisk virksomhed. Som ejer af kapital konkurrerer staten med andre enkeltkapitaler. Denne statsvirksomhed adskiller sig ikke fra andre enkeltkapitaler - alle er underkastet den kapitalistiske værdiproduktions og -realisations love. Staten har kun betydning 
som den formelle ejer af kapital, der er underkastet kapitalismens love, formidlet af konkurrencen. Det er tydeligt, at i dette tilfælde indsnævres de privatopererende enkeltkapitalers kapitalakkumulationsområde. Under en depression, når kapitalen ikke længere akkumulerer, kan udbygningen af en statskapitalistisk sektor indenfor den kapitalistiske økonomi - blandingsøkonomi - være den eneste mulighed for at styre samfundet og behandle de voksende arbejdsløshedsproblemer og tilhørende problemer med tiltagende sociale og politiske konflikter. Denne situation var det udgangspunkt, hvorfra Keynes udviklede sin teoretiske argumentation for statsintervention, udvidelse af statsaktiviteter og forstørrelse af den statslige sektor. Men under en højkonjunktur (boom) gælder, at kapitalen også ønsker at akkumulere indenfor områder, hvor staten har eller havde størstedelen af sine aktiviteter, og ved at forblive i disse områder ville staten modvirke kapitalen i dennes drift mod stadig tiltagende akkumulation. Staten ville herigennem frembringe skærpede konflikter som ville tvinge den til at lade privat kapital akkumulere og til at begrænse den statskapitalistiske sektor, enten gennem reprivatisering, gennem en subventionspolitik eller ved andre midler. Hvis vi f.eks. ser på statsaktiviteterne i Vesttyskland efter 2. verdenskrig, er man i stand til at tegne en kurve, der er negativt korreleret med kurven for den kapitalistiske udvikling: Igennem det »økonomiske mirakel « falder statsaktiviteterne relativt, mens de stiger igen i tresserne og især halvfjerserne. Dette er et udmærket eksempel på, at staten og statsaktiviteter er bundet til kapitalakkumulationsprocessen og at dette bånd selv fremtræder som strukturelle finanskriser.

Statsaktiviteternes finansielle restriktioner er påtvungne restriktioner, som udspringer af de begrænsede instrumenter, der er til statens rådighed. Det er temmelig modsigelsesfyldt, at staten skulle være i stand til at regulere en $\emptyset$ konomi med instrumenter, som den før fra den samme $\varnothing$ konomi; $\varnothing$ konomiens modsigelser må derfor afspejle sig som modsigelser mellem de forskellige $\varnothing \mathrm{ko}-$ nomiske styringsinstrumenter. Deraf følger, at staten ikke kan være autonom, men på grund af samfundets modsigelser, må den være særdeles forudindtaget (biased). Som konsekvens heraf må teorier som Hilferdings om staten som styrende subjekt og den organiserede kapitalisme som det styrede objekt være forkerte og falske reflektioner over den sociale virkelighed. Udover instrumenternes modsigelsesfyldte karakter (»den magiske trekant«) er der grænser for disse instrumenters effektivitet på grund af, at privat ejendomsret til produktionsmidlerne begrænser området for statslig aktivitet. Regulerende statslig $\varnothing$ konomisk politik finder sted indenfor cirkulationens område og ikke i produktionen. Den $\varnothing$ konomiske politiks instrumenter består typisk af pengepolitik, finanspolitik og politiske indgreb i forbindelse med konjunkturcyklen o.s.v. Disse instrumenter er klart kun indirekte fungerende værktøj, de er i stand til

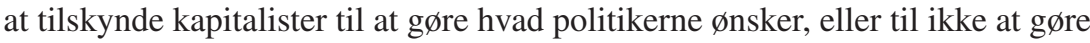
det og i sidste tilfælde findes der i det store og hele ingen sanktioner, der kan tvinge kapitalister til at gøre der »rigtige «. 
Det er klart, at hvis staten var i stand til at tvinge kapitalister som enkeltkapitalister til at handle som om de var legemeliggørelsen af hele systemets rationalitet, ville systemet ændres til et andet, og det ville ophøre med at være kapitalistisk. Det betyder, at enten må staten indordne de individuelle kapitaler under hele systemets generelle, overordnede rationalitet eller også vil det være umuligt at nå statsinterventionernes mål, hvilket kommer til udtryk i de mange fors $\emptyset \mathrm{g}$ på planlægning i kapitalistiske lande. Staten må naturligvis planlægge, men planerne kan kun være retningsgivende, ikke obligatoriske. Det sidstnævnte tilfælde kræver ikke alene en ændring af samfundet, men endda en drejning af staten selv fra en parlamentarisk republik til en autoritær stat, som vi kender den i den fascistiske udgave. Jeg mener, at det umulige i at styre samfundet og pacificere det med de begrænsede instrumenter, er en af de vigtigste grunde til de forskellige fors $\emptyset \mathrm{g}$ på at undertrykke sociale modsigelser, som dæmper statsaktiviteternes effektivitet, i en repression som den brutale fascistiske. Naturligvis er den autoritære stat under kapitalistiske betingelser i et vist omfang mere effektiv end den demokratiske. Derfor er $\emptyset$ nsket fra mange rene videnskabsmænd verden over om mere effektivitet samtidig et $\emptyset$ nske om mere effektive politiske processer, om styrkelse af den udøvende magt for at kunne gennemføre de såkaldte almene interesser mod arbejderklassens og enkeltkapitalers særlige interesser. Modsigelsen mellem instrumenternes begrænsninger og nødvendigheden af $\varnothing$ konomisk styring betyder, at der altid eksisterer en tendens i statsbureaukratiet til at løse denne modsigelse ved at udvide instrumenternes omfang og effektivitet ved en centralisering af den politiske magt og eliminering af modstående interesser på den politiske arena: demokratiets forsvinden.

Vi kommer nu til den tredie årsag til begrænsninger i statsinterventionerne, og som omfatter de sociale ejendommeligheder der udspringer af tradition, sociale erfaringer, politisk kultur og ikke mindst af forholdet mellem arbejdere og kapitalister, herunder graden af organisering i arbejderklassen. Økonomisk management betyder altid indgreb i konflikten mellem kapital og arbejde, og interventionernes effektivitet er afhængig af de to klassers styrke, henholdsvis deres organisationers. Dette forhold er næsten selvindlysende, når det drejer sig om indkomstpolitik.

Fagforeningernes karakter er f.eks. afgørende for accepten eller forkastelsen af indkomstpolitik. Fagforeningernes karakter er afhængig af erfaringerne i klassekampen, også af den teoretiske tradition, af den indre organisationsstruktur o.s.v. Naturligvis også af den generelle $\emptyset$ konomiske situation, men jeg mener, at de nævnte faktorer er vigtigere end den generelle $\varnothing$ konomiske situation. Det er måske muligt at forklare, hvorfor staten begynder med at regulere indkomster ud fra særtrækkene i et lands økonomiske situation - og man kan måske sige at indkomstpolitik finder sted når der ikke findes andre midler til at forøge udbytningsraten for at opretholde en given profitrate, nødvendig for kapitalakkumulationen. Men statens hensigter kan ikke udløses automatisk, og det er tydeligt, at hindringer for at realisere indkomstpolitiske mål kan stamme fra arbejderes opposition. 
Dette forhold er endnu et eksempel på den tidligere nævnte hypotese om den $\varnothing$ konomiske og politiske kamps udelelighed. Arbejderklassens »politiske kultur « har en stor $\emptyset$ konomisk indflydelse på statens politik og naturligvis på kapitalens akkumulationsproces, og bliver således en $\varnothing$ konomisk faktor. Det må dog fastslås, at dette forhold ikke kan bruges til at eftervise en antagelse om, at det politiske system er underkastet samfundets udvikling. Det er kun i stand til at modificere visse tendenser, og derudover formidlet af erfaringer, især af $\varnothing$ konomiske forhold, tendenser, kampe o.s.v. Betydningen af det politiske systems modificerende effektivitet skal derfor ikke overvurderes.

Men samtidig skulle det være indlysende, at politiske faktorer for en tid kan have en meget stor effekt på statsaktiviteterne. Det er let at finde empiriske eksempler på dette. F.eks. har klassekampen i Italien skabt en situation med arbejderinitiativ som modgår ikke alene statens $\emptyset$ konomiske politik men også kapitalens akkumulationsbestræbelser. Et andet eksempel er England, hvor de traditionelt militante arbejdere hindrer »regulerede arbejdsmarkedsforhold «, som er en forudsætning for store firmaers langtidsplanlagte kapitalakkumulation.

Det må understreges, at tradition er fremkommet alene gennem erfaringer, og erfaringer stammer fra situationer, som så igen er fremkaldt af særlige $\varnothing$ konomiske problemer. Det ville derfor være forkert at fremhæve den revolutionære politiske tradition i den italienske arbejderklasse og fremhæve den reformistiske i den tyske eller svenske arbejderklasse. De økonomiske forhold, der kommer til udbrud i en krise, frembringer også arbejdererfaringer, som i det lange løb konstituerer revolutionær bevidsthed eller i det mindste organisationer. Det er vigtigt at unders $\varnothing$ ge den måde, gennem hvilken der nu frembringes hindringer for statsaktiviteter: Økonomiske kriser frembringer erfaringer, som konstituerer politiske strukturer og organisationsmønstre, som bliver hindringer for statens handlinger, fordi den nu organiserede og bevidste magt vil modarbejde statsinterventioner i alle de tilfælde, hvor de skader de bevidste interesser. Som Schumpeter skrev, skaber kapitalen selv strata og organisationer, som er de bedste og mest effektive kæmpere mod kapitalens herredømme.

Den sidste af de fire årsager til begrænsninger i statsaktiviteter har at gøre med staten som en nationalstat på verdensmarkedet. Der skulle imidlertid en ny forelæsning til for at tale om de modsigelser der stammer fra og er konstitutive for det kapitalistiske verdensmarked. Men alt taler for en antagelse om, at mange alvorlige konflikter i den statslige politik skyldes afhængighed af verdensmarkedet. De kan være frembragt af kriser i det internationale valutasystem, af devaluering eller revaluering af valutakurser, gennem nationalisering af industrier, at voldsomme prisbevægelser o.s.v. Disse faktorer er særdeles vigtige, fordi de har to fællestræk: for det første er de på ingen måde håndtérbare af nationalstater, og for det andet udøver de en meget stærk indflydelse på den nationale økonomi. I denne sammenhæng får internationale firmaer en central betydning, fordi de udøver en $\varnothing$ konomisk magt, som får en politisk dimension ved at spille nationalstater ud mod 
hinanden for selv at maksimere profitter. For at komme ud over dette alvorlige problem forsøger nationalstaterne at kombinere deres magt for at kæmpe mod internationale firmaer og disses inflationsskabende effekter i den nationale politik. Men der er snævre grænser: Staten forbliver nationalstat, og det betyder materielt, at den kun bevidst er i stand til at regulere den nationale økonomi (indenfor de ovennævnte grænser). Selv om den skulle blive til en verdensomspændende stat - en absurd ultraimperialistisk antagelse - forbliver kapital delvis national, delvis international - en modsigelse der ikke kan løses af den borgerlige stat.

Følgerne af alt dette skulle være meget enkle: også under monopolistiske betingelser findes der grænser for statens handlinger. Disse grænser kan kun være til stede, hvis der ligeledes findes en bevægelseslov for det kapitalistiske samfund og ikke et enkelt eller simpelt forhold mellem et styrende subjekt, d.v.s. staten, og et styret objekt, d.v.s. $\varnothing$ konomien. Men dette er kun den ene halvdel, for selv under monopolistiske betingelser er staten ikke et autonomt subjekt, ikke engang i den forstand at den udelukkende er et instrument for monopolerne til at plyndre alle andre lag i samfundet. Samtidig er det imidlertid korrekt, at statsinterventionerne tiltager kvantitativt med tiltagende monopolisering. Jeg mener at begge tendenser skyldes samme årsag, nemlig tendensen til en faldende profitrate, som på den ene side tvinger kapitalen til at kompensere for den faldende profitrate gennem voksende profitmasser og på den anden side tvinger staten til at gribe ind politisk.

Denne sammenhæng mellem voksende kapital og tiltagende statsinterventioner udgør den logiske begrundelse for statsmonopolkapitalismeteorien. Men vi har nu set, at de følger, som stamokap-teorien udleder, ikke holder: især antagelsen om staten som en ret autonom institution overfor samfundet, idag under monopolernes herredømme, men imorgen takket være det antimonopolistiske folk, måske under folkets herredømme - denne antagelse forbliver problematisk. Forholdet mellem monopol og stat er mere komplekst end det antages i de almindelige stamokapteorier.

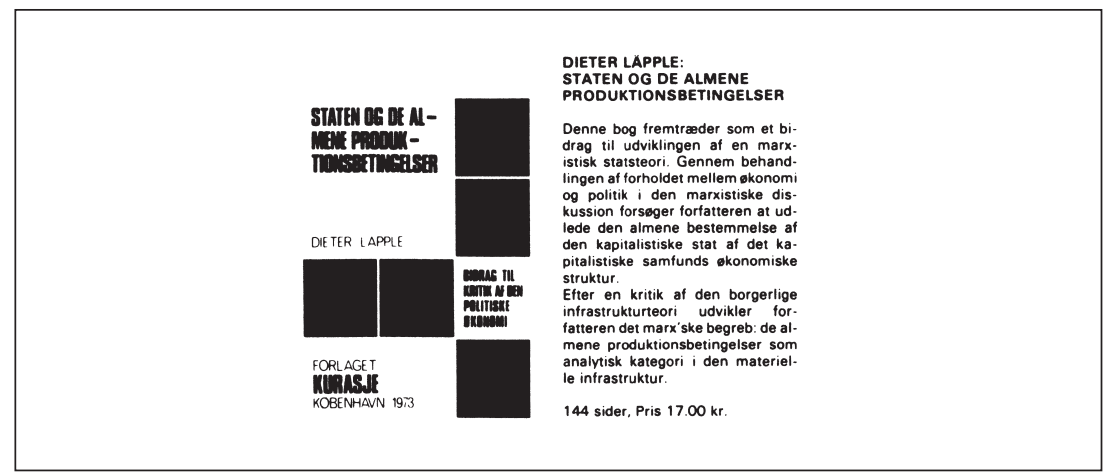

